\title{
100 LET VZTAHU STÁTU S CÍRKVEMI, 100 LET KŘIVD A SVÁRU゚*
}

\author{
PETR KAROLA
}

\begin{abstract}
: $\quad 100$ years of relationship among state and churches, 100 years of grievances and feuds How can be the development of the relationship between the Czech state and churches and religious societies characterized in the period since the establishment of the restored Czech statehood in the year 1918 to the present? The author of this article focuses on the historical genesis of the often complicated relationship between Czech society and churches and the Roman Catholic Church in particular. The author tries to describe the centennial development of particular approaches of political representation from the formation of the Czechoslovakia up to now which deals with the question of separation and public supervision over the churches and other religious societies including their funding.
\end{abstract}

Keywords: the relationship between church and state; churches and religious societies; historical genesis

Klíčová slova: vztah státu s církvemi; církve a náboženské společnosti; historická geneze

DOI: $10.14712 / 23366478.2018 .17$

\section{ÚVODEM}

Základní rámec vztahu Čechů $\mathrm{k}$ církvím ${ }^{1}$ byl limitován především jejich ztrátou důvěry a respektu ke katolicismu, jeho hodnotám a k Ř́mskokatolické církvi zvláště. Spor o smysl českých dějin, který vedl Tomáš Garrigue Masaryk především s Josefem Pekařem, není ani po 100 letech uzavřen. Naopak, v kontextu znovu ožívající debaty o tzv. církevních restitucích je tento „spor“ znovu aktuální. Filozof Masaryk, který názorově vystupoval proti katolicismu především s vědomím, že je klíčovou oporou Habsburské monarchie, reprezentující spojení trůnu a oltáře, tak formuloval základní postoj národa $\mathrm{k}$ Ř́mskokatolické církvi, který stále většinově přetrvává. Nekompromisně požaduje odluku církve od státu bez ohledu na skutečnost, že představy politických reprezentací byly, co se týká rozsahu a provedení, odlišné. Zde je třeba připomenout, že

* Tento článek byl vypracován v rámci programu PROGRES Q04. Autor je doktorandem na katedře ústavního práva Právnické fakulty Univerzity Karlovy.

1 Pro lepší orientaci v textu bude k označení církví a náboženských společností používáno souhrnného názvu „církve“. 
požadavek odluky nebyl ani po sto letech od vzniku Československa důsledně naplněn. Vztah státu s církvemi tak v našich podmínkách nejspíš ještě dlouho zůstane poznamenán idealizací humanismu jednoty českobratrské a zatížen českým národovectvím potlačovaným v období protireformace, zároveň posilovaným násilnou rekatolizací. Doba pobělohorská je proto stále vnímána jako úpadek českého státu, jazyka a kultury. Výše uvedené důvody nepř́źznivě ovlivňují vztah české společnosti k církvím i náboženským společnostem. Nemůže být tedy překvapením, že k náboženské viřre se při posledním sčitání lidu přihlásila pouhá pětina obyvatel České republiky. ${ }^{2}$ To nás dlouhodobě řadí mezi jeden z nejvíce ateistických národů na světě.

Jak jsem rozebral ve své předchozí práci: „,éměr celou historickou epochu existence církví a náboženských společností na území dnešní České republiky byl, jak nad jejich činností, tak nad jejich majetkem vykonáván veřejný dozor. "3 Tento dozor, at' už v podobě dohledu panovníka (donora) a následně státu, neměl v průběhu času stejnou intenzitu a prošel složitým nelineárním vývojem. Demonstrovat to můžeme na pohybu kyvadla. Periodu a výchylku pomyslného kyvadla vždy určoval konkrétní politický systém, jeho reprezentace i představy jak by měla odluka vypadat, které se vždy lišily. Odluka církve od státu nemusí mít vždy tu samou povahu. Ne vždy automaticky garantuje svobodu vyznání pro všechny a svobodné církve. Nicméně, u nás v podstatě nikdy, od vzniku Československé republiky, nebyl požadavek samotné odluky výrazným způsobem zpochybněn.

V posledních sto letech zaznamenáváme období vyznačující se důrazným dohledem a kontrolou náboženského života a ta byla následně stř́ídána periodou uvolnění. Všechna tato období však spojuje pokus o nastavení „nějakých“ pravidel odluky. Tedy, o způsobu, formě a rozsahu, kterým by bylo zajištěno odstranění výjimečného postavení církví ve společnosti, s následným podřizením kontrole moci veřejné. Jednu krajní polohu kyvadla ovlivněného, jak tradičním protikatolickým postojem, tak tragickými důsledky 2. světové války, reprezentuje extrémní zostření veřejného dozoru nad činností a majetkem církví po Únoru 1948. Druhou krajní polohu reprezentuje překotně organizované rušení tohoto dozoru po roce 1989. Výsledkem je druhý extrém, a to jeho úplná absence. Ve svém textu se proto pokusím pokrýt čtyři logicky navazující periody společenského vývoje. První popisuje situaci v Československé republice. Druhá část pokrývá vývoj v letech nástupu vlády Komunistické strany Československa až do roku 1989. Třetí se zaměřuje na období po Listopadu 1989 až do tzv. majetkového vyrovnání státu s církvemi v roce 2012 a poslední část se dotkne současného stavu.

\section{VZTAH MEZI CÍRKVEMI A STÁTEM V OBDOBÍ 1918-1949}

I když v první československé republice nebyl „Kulturkampf“ nikdy organizovaný státem, tak jako v např. v bismarckovském Německu, i tak to neměly církve

2 Zjiššení Českého statistického úřadu vyplývající ze sčítání lidu provedeného v roce 2011. Dostupné online: https://www.czso.cz/documents/10180/20551795/17022014a02.pdf/3cb6b892-beec-4ea3-8a7e -5444ab95dae8?version=1.0 [cit. 20. 1. 2018]

3 KAROLA, Petr. Problematika tzv. Církevních restitucí po roce 1989. Praha, 2014. Diplomová práce. Karlova univerzita v Praze. Právnická fakulta. Katedra ústavního práva, s. 15 
a dvojnásob to platí o té Římskokatolické, př́liš jednoduché. Vyhlášení Československé republiky představovalo logicky zásadní zvrat v dosavadním postavení Římskokatolické církve, která byla v očích „československého národa“ spojována s útlakem sesazené monarchie. Dekády demonstrovaný antiklerikalismus mladočechů, následně převzatý v podstatě téměř všemi politickými stranami, posílený předchozími postoji T. G. Masaryka vyjádřenými napřr. ve Washingtonské deklaraci, přinesly své ovoce. A to i přesto, že reálnou politiku nového prezidenta, ve věci vztahu k církvím, lze charakterizovat až na pár excesů jako opatrnou. Situaci rozhodně neprospěli ani výroky Vídeňského nuncia Teodora Valfre di Bonzo, který v turbuletní době formování nového státu vystupoval proti Spojení Slovenská s českými zeměmi a prosazoval zachování uherské koruny v historické hranici. ${ }^{4}$ Provedení odluky, v různých formách, obsahovaly programy většiny politických stran. Nejznámějším projevem vyhrocené společenské nálady představuje zničení mariánského sloupu na Staroměstském náměstí (dne 3.11. 1918) davem, který vedl známy pražský bohém, spisovatel, přítel Jaroslava Haška a radikál František Sauer. O kontroverzi tohoto činu nejlépe vypovídá fakt, že i bezmála po sto letech od této událostí vyvolala snaha prosadit obnovení sloupu silné emoce. V záŕí roku 2017 pražské zastupitelstvo tuto iniciativu jednoznačně odmítlo.

Vrcholní představitelé státu, spolu s akademickou inteligencí se ničení památek s náboženskou tématikou snažili zabránit, obvykle však bez kladného výsledku. V excitované společenské atmosféře se chystala nepřátelská forma odluky církve od státu, doprovázená zabráním významné částí majetku církví a pod bojovnými hesly, jako např.: „Po Vídni Řím!“"5 Nutno zdůraznit, že i přes tyto proklamace nikdy ke konečnému „zúčtování s Římem“ v Československu nedošlo. Z části i kvůli složité vnitropolitické situaci, kterou vyvolala potřeba brát ohled na silně katolické Slováky a řeckokatolickou Podkarpatskou Rus. V politických vyjednáváních se střetly návrhy inspirované modelem francouzské odluky (dle modelu z roku 1905) s Washingtonskou deklarací akcentovanou odlukou anglosaského typu, dokonce i s odlukovým modelem sovětským. Přes všechno však zůstává faktem, že celková intenzita veřejného dozoru nedosahovala za první republiky ani zdaleka takových rozměrů jako v období po roce 1949, i když spousta mechanismů využitých totalitním režimem našla svůj předobraz právě v období první republiky, př́padně trochu paradoxně až v sesazené monarchii (josefínské reformy). Slovenští katolíci, společně s těmi českými, vedli, v prvních letech tvrdý boj směřující k zabránění odluky církve od státu. Politickou složku obou národních proudů katolicismu reprezentovala, záhy po vzniku nového státu, sjednocená Československá strana lidová6 opřená o silnou Slovenskou l'udovou stranu, která se na rozdíl od ní těšila široké podpoře slovenského obyvatelstva. Nejdůležitější bitva se však jednoznačně odehrála už při formování ústavy nově vzniklého státu. Prezident Masaryk prosazoval ústavní zakotvení odluky. Původní § 121 jednoho z návrhu ústavy tak zněl odlišně, než jej známe

4 DEJMEK, Jindřich. Počátky diplomatických vztahů mezi Československem a Vatikánem (1920-1921). Český časopis historický, roč. 91, č. 2, 1993, s. 224.

5 KADLEC, Jaroslav. Přrehled českých církevních dějin. Praha: Zvon, 1991, s. 239.

6 HALAS, František X. Fenomén Vatikán: idea, dějiny a současnost papežství: diplomacie Svatého stolce: České zeméa Vatikán. 2., rozš. vyd. Brno: Centrum pro studium demokracie a kultury (CDK), 2013, s. 550, 553. 
dnes. Psalo se v něm: „Mezi státem a církvemi budiž zaveden stav odluky““. ${ }^{7} \mathrm{~V}$ konečném znění, po mnoha zuřivých debatách, se však tato formulace nikdy neobjevila, a to v důsledku striktního stanoviska slovenského poslaneckého klubu. ${ }^{8}$ Nakonec byl prosazen $\S 121$ ve znění: „Svoboda svědomí a vyznání jest zaručena.“. Tento kompromis byl přijat $\mathrm{v}$ podstatě proto, aby nedošlo $\mathrm{k}$ zablokování prrijetí nové ústavy. Neopomenout musíme i návrh poslance Bartoška, který podal návrh zákona o odluce. Ten byl však většinově odmítnut. Po roce 1922 začalo být více než jasné, že se politické reprezentaci nepodaří sjednotit na společném názoru, jak by měla plánovaná odluka vypadat. Tento stav „zabetonovalo“, když do vládní koalice vstoupila Československá strana lidová. A dále umocnilo přijetí jejího předsedy J. Šrámka do tzv. Pětky, jež v první půli dvacátých let prakticky ř́́dila politický život $\mathrm{v}$ zemi. Zde nacházíme paralelu k situaci z roku 2014, kdy do vlády B. Sobotky vstoupila strana KDU-ČSL a tím „spadla pod stůl“" slibovaná revize zákona o majetkovém vyrovnání státu s církvemi a náboženskými společnostmi. I přesto, že byl novým státem právní řád Rakouska-Uherska, s dílčími výjimkami, převzat tzv. recepční normou, některé zákony, regulující postavení církví, např. v oblasti školství byly následně upraveny pro církve výrazně méně příznivě. A to i přes stále chybějící odluku. Naopak, závislost církve na státu, zavedena především zákony z roku 1874, byla zachována a v některých aspektech dokonce prohloubena. Tzv. malým školským zákonem z roku 1922 byla zrušena povinná výuka náboženství na školách. Na druhou stranu se církvím podařilo udržet možnost církevního sňatečného obřadu i odolat snahám o převzetí matrik. ${ }^{9}$ Co se týká majetku církví, ten výrazně omezila pozemková reforma probíhající v letech 1918 až 1936, kdy byla přechodně zastavena z nedostatku státních finančních prostředků i zájmu o půdu..$^{10}$ Není potřeba dodávat, že nejvíc byla pozemkovou reformou postižena právě Rímskokatolická církev. Závislost církve na státu byla dále podpořena přijetím tzv. Kongruového paragrafu $\mathrm{v}$ rámci dohody agrární a lidové strany s cílem prosadit uzákonění cel na dovoz zemědělských výrobků. V rámci tohoto paragrafu byl stanoven základní kněžský plat, který byl zajišt'ován ze státních prostředků. Jednalo se o jednu z největších ran plánované odluce. ${ }^{11}$ Až do roku 1928 procházel divokými turbulencemi oficiální mezinárodní, diplomatický vztah nové republiky se Svatým stolcem. Ze začátku se dokonce hovořilo až o absurditě navázání diplomatických styků. Tento postoj se však po ustálení situace a při vědomí, že i když došlo k úbytku obyvatel hlásících se k římskokatolickému vyznání, tak Československo, zvláště pak Slovensko zůstane stále převážně katolické, postupně vytratil a převládl politický pragmatismus. Kličovou roli v nápravě tohoto vztahu sehrál profesor Kamil Krofta, který byl jako historik, specializující se na problematiku církví,

7 KOLÁŘ, Petr. Myšlenka odluky státu a církve v období vzniku první Československé republiky. In: KOLÁR̆, Petr. In omnibus caritas. K poctě devadesátých narozenin prof. ThDr. Jaroslava Kadlece. Praha: Karolinum, 2002, s. 304-335, s. 328-332.

8 PAVLÍČEK, Václav. O české státnosti: úvahy a polemiky. 3. Demokratický a laický stát. Praha: Karolinum, 2009, s. 166.

9 KADLEC, Jaroslav. Přehled českých cirkevních dějin 2. Praha: Zvon, 1991, s. 243.

10 MALÝ, Karel a kol. Dějiny českého a československého práva do roku 1945. 4. přeprac. vyd. Praha: Leges, 2010, s. 413.

11 HALAS, František X. Fenomén Vatikán: idea, dějiny a současnost papežství: diplomacie Svatého stolce: České země a Vatikán. 2., rozš. vyd. Brno: Centrum pro studium demokracie a kultury (CDK), 2013, s. 577-578. 
jmenován vyslancem Československé republiky u Svatého stolce. I když jeho misi lze považovat za úspěšnou jen částečně. Nepodařilo se mu např. vyjednat úpravu práva $\mathrm{z}$ dob monarchie, nominovat biskupy. Nicméně, $\mathrm{v}$ zájmu spravedlnosti je třeba zdůraznit, že toto právo Svatý stolec nepřiznal žádnému z nových nástupnických států. Kromě negativního pohledu čelních představitelů státu, přípravy odluky a probíhající pozemkové reformy komplikoval vztah se Svatým stolcem rovněž jeho odpor k rehabilitaci Jana Husa. Př́pravy nové mezinárodní smlouvy se Svatým stolcem započaly s výměnou nuncia Clementa Micary. Jednání byla velmi obtížná a táhla se dlouhé roky. Vatikánu šlo o udržení co nejvíce aspektů původního vztahu s předchozí monarchií. Situaci rovněž neprospělo zrušení některých církevních svátků, vznik církve československé a rozkol v řadách katolických kněží. Negativní pohled Vatikánu ohledně oslav nově zakotveného Husova svátku posílila veřejná vystoupení prezidenta Masaryka a př́má účast československých představitelů na těchto oslavách. Tato situace vyústila až v demonstrativní odjezd nuncia Marmaggiho v rámci tzv. Marmaggiho aféry. I když Svatý stolec na více než rok zmrazil své styky s republikou, k vypovězení oficiálních diplomatických styků ani z jedné strany nedošlo. Další vyjednávání smlouvy započala $\mathrm{v}$ podstatě až v roce 1927, s tím, že byla dokončena již v prosinci téhož roku. Zajímavostí rozhodně je, že tato mezinárodní smlouva byla sjednána ještě před uzavřením tzv. Lateránských dohod ustanovujících Vatikánský stát. V roce 1928 byl uzavřen se Svatým stolcem tzv. Modus vivendi. Zde bylo mimo jiné dohodnuto, že žádné území Československé republiky nebude spravováno biskupem mimo její území a naopak. Smlouva obsahovala pouhých šest článků a Svatý stolec se zavázal upravit hranice diecézí dle hranic nového státu. Problematika jmenování církevních představitelů byla vyřešena kompromisem. Před jmenováním církevního představitele musel Svatý stolec oznámit československé vládě návrh kandidáta. Vláda pak mohla vznést námitky, zejména pokud šlo o bezpečnost státu. Všichni jmenovaní církevních hodnostáŕi museli nakonec i složit slib věrnosti československému státu. Byla i ukotvena nezbytnost československého státního občanství u vedoucích představitelů řeholí. Prezident Masaryk však smlouvu přesto nikdy nepodepsal, i když byla platná na vládní úrovni. Dokonce ani nevyšla ve Sbírce zákonů. ${ }^{12}$ Z hlediska práva nebyl Modus vivendi nikdy zrušen přesto, že nebyl fakticky desetiletí naplňován a obě strany $\mathrm{v}$ devadesátých letech 20 . století konstatovaly, že jej považují za neplatný a neúčinný. ${ }^{13}$

Politický katolicismus po roce 1929 postupně slábne. Lze však konstatovat, že se církvím a především té Římskokatolické podařilo, i přes řadu nesnází a turbulencí, uhájit značnou část svého předchozího postavení. Svoji roli v tom bezesporu sehrála i rychlá obměna vrcholných představitelů církve, $v$ čele s výrazným arcibiskupem Kordáčem. Veřejný dozor státu se soustředil spíše na nedůslednou regulaci a vyvlastnění majetku církví, než na omezování její činnosti a fungování. Jedná se tedy spíše o období nižší intenzity dozoru. I preses jednoznačně čitelný požadavek na odluku, o odluce v pravém

12 PAVLÍČEK, Václav. O české státnosti: úvahy a polemiky. 3. Demokratický a laický stát. Praha: Karolinum, 200, s. 182.

13 HALAS, František X. Fenomén Vatikán: idea, dějiny a současnost papežství: diplomacie Svatého stolce: České země a Vatikán. 2., rozš. vyd. Brno: Centrum pro studium demokracie a kultury (CDK), 2013, s. 565-583. 
slova smyslu hovořit nelze. V některých aspektech, jako např. u financování, docházelo k jejímu pravému opaku.

Tak, jak se podařilo Ř́mskokatolické církvi ve složitých dobách formování nového státu až neuvěřitelně dobře obstát, totéž pro ni neplatí v období po Mnichovu až do 80 . let 20. století. Její situace se až na výjimky kontinuálně zhoršovala a ingerence státu $\mathrm{v}$ rámci veřejného dozoru postupně dosahovala svého vrcholu.

Dobu po podepsání Mnichovské dohody, II. Republiky až do skončení druhé světové války není nutné pro potřeby tohoto článku detailně rozebírat. Podstatná byla bitva o samotnou existenci státu a pro exilovou i protektorátní vládu nebyl vztah s církvemi zásadním tématem. Po skončení války se v legislativě orientované na církve setkávají dvě protichůdné tendence. První se týkala nápravy křivd, které byly církvím spáchány v období po „mnichovské zradě“ a druhá se zaměřila na vypořádání se s kolaboranty formou konfiskace jejich majetku, což reprezentují zejména dekrety prezidenta republiky. ${ }^{14}$ Celkový př́istup Římskokatolické církve k Mnichovu a době po něm lze hodnotit jako rozpolcený. Na jedné straně jej reprezentuje diplomaticky opatrný nesouhlas Svatého stolce s Mnichovskou dohodou, odboj některých známých českých katolíků a kněží, na druhé pak kolaborace, a to jak řadových členů, tak jejich špiček, umocněná složitou vnitropolitickou situací na Slovensku, konkrétně klerofašismem, který se zde prosadil a se kterým navázal Svatý stolec oficiální diplomatické styky prostřednictvím Slovenského štátu. ${ }^{15}$ Představitelé Římskokatolické církve tak v roce 1943 vydali pastýřský list kritizující kobercové bombardování Německa západními státy a v témže roce odsoudili dokonce i válečné akce Sovětského svazu. ${ }^{16}$ Československá reprezentace nelibě nesla př́stup Svatého stolce k otázce kontinuity Československa a jeho podporu slovenského separatismu. Marně se prezident Beneš i lidovec Šrámek domáhali uznání kontinuity státu ze strany Svatého stolce. I přesto však nakonec Košický vládní program obsahoval záruky plné náboženské svobody. ${ }^{17}$ Perioda $1938-1948$ je jednou z nejzajímavějších kapitol historie vztahu státu a církví. Nejprve extrémní zpř́ísnění dozoru a perzekuce církví z let válečných, krátké uvolnění dozoru v době těsně poválečné, nakonec znovu eskalace dozoru a zásahů směřujících $\mathrm{k}$ Únoru 1948. V této souvislosti nesmíme opomenout na snahu dokončit pozemkovou reformu, jejíž praktické provedení bylo za První republiky k církvím značně velkorysé. A to až tak, že jim ve vlastnictví zůstalo 84,14 \% zabrané půdy. Vzhledem k tomu o jak krátký časový úsek se jedná

14 Dekret prezidenta republiky č. 5/1945 Sb., o neplatnosti některých majetkově-právních jednání z doby nesvobody a o národní správě majetkových hodnot Němců, Mad’arů, zrádců a kolaborantů a některých organisaci a ústavů, dekrety prezidenta republiky č. 12/1945 Sb., o konfiskaci a urychleném rozdělení zemědělského majetku Němců, Mad’arů, jakož i zrádců a nepřátel českého a slovenského národa a č. 108/1945 Sb., o konfiskaci nepřátelského majetku a Fondech národní obnovy.

15 KONÍČEK, Jiří. Modus vivendi v historii vztahů Svatého stolce a Československa: cirkevně-politický vývoj v letech 1918-1993. Olomouc: Společnost pro dialog církve a státu, 2004, s. 139-144.

16 BRANDES, Detlef. Češi pod německým protektorátem: okupační politika, kolaborace a odboj 1939-1945. 2. vyd. čes. jaz. Praha: Prostor, 2000.

17 HALAS, František X. Fenomén Vatikán: idea, dějiny a současnost papežství: diplomacie Svatého stolce: České země a Vatikán. 2., rozš. vyd. Brno: Centrum pro studium demokracie a kultury (CDK), 2013, s. 622. 
a s ohledem na to jakým překotným vývojem v něm prošel př́istup státní moci $\mathrm{k}$ církvím, lze bezpochyby říci, že se jednalo o bezprecedentní situaci. ${ }^{18}$

\section{VÝVOJ V LETECH 1948-1989}

Lze konstatovat, že snad jen s výjimkou josefínských reforem je období let 1949-1989 charakteristické vrcholnou úrovní intenzity veřejného dozoru státu nad církvemi a náboženskými společnostmi. Přitom, společenská atmosféra se po 2. sv. válce od roku 1918 diametrálně lišila. Veřejnost byla církvím nakloněna příznivěji. Ani komunisté nevystupovali s protináboženskou rétorikou nijak intenzivně. Naopak, z počátku tlumili proti církevní hlasy i ve vlastních řadách. Obyvatelstvo vnímalo, že církve neunikly nacistické perzekuci a že se někteří jejich představitelé účastnili odboje. A kladně přijato bylo i obsazení biskupských stolců bývalými kněžími vězněnými v koncentračních táborech, tedy Josefem Beranem a Štěpánem Trochtou. ${ }^{19} \mathrm{Na}$ druhou stranu, vztahu společnosti k církvi, zvláště té Římskokatolické zásadním způsobem ublížilo klerofašistické dědictví Slovenského štátu, v čele s knězem Josefem Tisem. Tak, jak se slovenským lidovcům dařilo brzdit a tlumit požadavek odluky za první republiky, šance dosáhnout podobného výsledku byla po válce takřka nulová. Šrámkovi lidovci na tento úkol sami stačit nemohli. Zvláště pak za situace, kdy se za notné pomoci Josefa Plojhara Československá lidová strana stala nástrojem Národní fronty. Ač je tedy na Slovensku patrná práce Demokratické strany, která se spolu se Stranou svobody stala novým reprezentantem slovenského politického katolicismu a alespoň krátkou dobu úspěšně čelila tlaku Komunistické strany Slovenska. Komunisté byli především zaskočení značným úspěchem Demokratické strany ve volbách v roce 1946. Pro představitele nově se rodícího režimu byl vztah státu a církve jednou z klíčových agend. O negativním postoji k náboženství a církvím jako celku nelze mít pochyby. Ještě daleko před Únorem 1948 je, jak ve vystupování, tak i v praktické politice Komunistické strany Československa (dále jen KSČ) patrná snaha prezentovat společnosti náboženství jako „opium lidstva“ a jako náhradu za náboženství nabízet svou vlastní ideologii. Nicméně, bylo by nesprávné tvrdit, že KSČ změnila svůj umírněný postoj vůči Římskokatolické církvi okamžitě po Únoru 1948. Celý vývoj tohoto vztahu byl daleko složitější a z počátku nebylo vyloučeno, že mezi oběma tábory dojde k dohodě. ${ }^{20} \mathrm{KSČ}$ šlo v podstatě o to, podřídit Římskokatolickou církev státu prostřednictvím ,„prátelských“ biskupů, oddělit ji od Vatikánu a postupně ji přetvořit v církev národní, jejíž hierarchii by jmenoval stát. Nižší duchovní si pro vyjednávání s vládou založili tzv. Mírové hnutí katolického duchovenstva, a to za hlasité podpory státního aparátu. Jednání na vyšší úrovni pak probíhala skrze Československou biskupskou konferenci. Při vyjednáváních s představiteli

18 KAROLA, Petr. Problematika tzv. Cirkevnich restituci po roce 1989. Praha, 2014. Diplomová práce. Karlova univerzita v Praze. Právnická fakulta. Katedra ústavního práva, s. 30-31.

19 HALAS, František X. Fenomén Vatikán: idea, dějiny a současnost papežství: diplomacie Svatého stolce: České země a Vatikán. 2., rozš. vyd. Brno: Centrum pro studium demokracie a kultury (CDK), 2013, s. 622, 628.

20 KAPLAN, Karel. Stát a církev v Československu v letech 1948-1953. Brno: Doplněk, 1993, s. 40. 
státní moci především vynikají postoje arcibiskupa Berana a biskupa Trochty, které se diametrálně lišily. S tím, že Trochta byl více nakloněn hledat pozici pro vzájemně výhodnou symbiózu církve s nově formovaným systémem. Avšak, jednání nespěla ke smírnému vyústění a od poloviny roku 1949 začalo docházet $\mathrm{k}$ násilným střetům a to nejenom ve směru k Římskokatolické církvi. V rámci tzv. „Akce P“ došlo k likvidaci Reckokatolické církve, která byla připojena $\mathrm{k}$ málo početné církvi Pravoslavné. Dále je nutné zmínit alespoň tzv. „Akci K“, zaměřenou na řády a kongregace. V důsledku ní došlo k nucené internaci 2.376 členů mužských řádů do devíti konkrétních klášterů. Zde byli souzeni za vykonstruované trestné činy a následně zařazováni do pracovních táborů. Hlavní vlna těchto procesů skončila v roce 1954. Nicméně, před veřejnými soudními procesy byla preferována ,pracovní převýchova“. Představitelé režimu se spíše vyhýbali veřejným procesům se špičkami církevní hierarchie, nebot’ ty byly negativně vnímány veřejným míněním ve zbytku světa. Nicméně použili je např. vủči spišskému biskupovi Vojtašákovi. Následoval zásah i proti ženským řeholím. ${ }^{21}$ Trochtovy snahy, vedené starostí o přežití církve, vyvrcholily 12. března 1951 složením slibu věrnosti republice, a to spolu s dalšími čtyřmi katolickými hodnostáři, dvěma českými a dvěma slovenskými. Ani tento ústupek však nestačil a Trochta byl v roce 1953 odsouzen k dlouholetému vězení. Jeho kolega Beran, prosazující tvrdší linii, byl v „domácím vězení“ již od roku $1949 .{ }^{22} \mathrm{Z}$ výše popsaného je jasné, že o formu odluky v klasickém smyslu nelze hovořit. Naopak, došlo k výraznému propojení církví se státním aparátem a ovládnutí jejich majetku. Přesto Ústava Československé republiky z roku $1948^{23}$ i Ústava Československé socialistické republiky z roku $1960^{24}$ obsahovaly ustanovení o svobodě náboženského vyznání, svobodě provádět náboženské úkony, včetně toho, že všechna náboženská vyznání i osoby bez vyznání jsou si před zákonem rovny. Nicméně, naplnění v praxi nikdy nefungovalo. Majetek církví, především té Římskokatolické, byl nejprve redukován postupem dle zákona č. 142/1947 Sb. z. a n., o revizi první pozemkové reformy. Následně postupem dle zákona č. 46/1948 Sb. z. a n., o nové pozemkové reformě. Správy některých majetkových podstat řádů a kongregací se, dle dalších předpisů, mnohdy jen vyhlášek, ujaly náboženské fondy, od roku 1951 Náboženská matice. Jak již bylo uvedeno, řada nástrojů, které tehdejší komunistická moc vůči církvím použila, našla svůj vzor až v dobách monarchie či období první republiky. V periodě od 14. do 25. října 1949 bylo přijato několik církevních zákonů. Jejich schválením došlo ke zrušení téměř všech předchozích předpisů věnujících se vztahu státu a církví. ${ }^{25}$ Za nejdůležitější z nich lze považovat zákon č. 218/1949 Sb., o hospodářském zabezpečení církví a náboženských společností státem. K provedení zákona

${ }^{21}$ KŘİŽ, Jakub; VALEŠ, Václav. Zákon o majetkovém vyrovnáni s církvemi a náboženskými společnostmi: komentáŕr. Praha: C. H. Beck, 2013, s. 140-141.

22 HALAS, František X. Fenomén Vatikán: idea, dějiny a současnost papežstvi: diplomacie Svatého stolce: České zemé a Vatikán. 2., rozš. vyd. Brno: Centrum pro studium demokracie a kultury (CDK), 2013, s. 635-638.

23 Viz $§ 16$ a 17.

24 Viz čl. 32.

25 Zákon č. 217/1949 Sb. zřídil Státní úřad pro věci církevní, zákon č. 218/1949 Sb., o hospodářském zabezpečení církví a náboženských společností státem, zákon č. 268/1949 Sb. přenesl vedení matrik na národní výbory. 
byla vydána vládní nařízení č. 219-223/1949 Sb., vztahující se k jednotlivým církvím a náboženským společnostem. Tento zákon se stal základním kamenem veřejného dozoru nad církvemi, který částečně přetrval i po roce 1989. Na základě této úpravy bylo možné duchovní úřad vykonávat jen s odvolatelným státním souhlasem. Zcizení nebo zatížení zbývajícího majetku církví podléhalo předchozímu souhlasu státní správy. Po vzoru prvorepublikového Kongruového paragrafu byl upraven i plat duchovních. Na druhou stranu, dosaženo bylo těch aspektů odluky, které se nepovedlo prosadit za první republiky. Předpisy nového rodinného práva byl zaveden obligatorní civilní sňatek a vedení matrik bylo preneneseno na správní orgány státu. Po celé toto období však existovala, byt' v omezené formě, i výuka náboženství ve školách. Dozor dosáhl úrovně, kdy byly, tzv. církevním tajemníkům, povinně předkládány ke schválení pastýřské listy, instrukce, oběžníky a všechny další tiskoviny určené kněžím i věřícím. Svoji obrodu zažil v rámci trestního práva i tzv. Kazatelnicový paragraf. ${ }^{26}$ Lze shrnout, že i když byl náboženský život a svoboda se sdružovat k výkonu obřadu na první pohled udržena, byla státním aparátem bedlivě sledována a vyhodnocována. Nejpečlivěji byla analyzována nálada v církevní obci, její velikost a aktivity veškerého charakteru. Věřícím i kněžím byl hustou sítí zákonů a nařízení nechán jen velmi malý manévrovací prostor. Jako za německé okupace, i ted' se našla řada duchovních, kteří s režimem spolupracovali dobrovolně. Platná právní úprava, 40 let postupně zostřovaná, často i prostředky mimo právní rád, neodpovídala požadavkům náboženské svobody.

Přesto by bylo ignorací tvrdit, že se vztah státu a církví do roku 1989 jenom zhoršoval. V důsledku rozsáhlých mezinárodních, vnitrostátních společenských a politických změn šedesátých let i KSČ začala uvažovat o určité revizi postavení církví. Dokonce připouštěla i jednání s Vatikánem. V roce 1962 povolila vláda výjezd třech biskupů na druhý vatikánský koncil a o rok později zahájila jednání s Vatikánem. Tato jednání vyústila napřs. v propuštění arcibiskupa Berana, stále drženého v domácím vězení. Předmětem těchto rozhovorů bylo, mimo „propuštění“ arcibiskupa Berana, např. obsazení volných biskupských stolců, úprava kněžského slibu věrnosti státu, výuka náboženství, vyřešení situace budoucnosti zrušených řádů a kongregací, svoboda pro církevní tisk, postavení řeckokatolické církve, otázka vězněných kněží apod. Největšího úspěchu dosáhly církve u otázky propuštění perzekvovaných kněží. Vleklá jednání se však v letech 1963-1967 zasekla. V období 1968-1969 dochází krátkodobě k uvolnění dozoru vůči církvím. V následné normalizaci z něj zbyla v podstatě jen obnova činnosti Řeckokatolické církve a obsazení některých prázdných diecézí novými biskupy. $V$ omezené formě pak probíhala jednání s Vatikánem kontinuálně až do roku 1989. Z iniciativ, které se pokoušely změnit přístup státu $\mathrm{k}$ církvím, nejvýrazněji vystupuje až pastorační iniciativa naplánovaná na roky 1987-1997, kterou vyhlásil v roce 1987 kardinál Tomášek. Ocitáme se v době probíhající „perestrojky“ a „glasnosti“ a českoslovenští katolíci začínají pocit’ovat, že ve vzduchu visí společenská změna. ${ }^{27}$

26 KAROLA, Petr. Problematika tzv. Církevních restitucí po roce 1989. Praha, 2014. Diplomová práce. Karlova univerzita v Praze. Právnická fakulta. Katedra ústavního práva, s. 15,16, 33, 34.

27 HALAS, František X. Fenomén Vatikán: idea, dějiny a současnost papežství: diplomacie Svatého stolce: České země a Vatikán. 2., rozš. vyd. Brno: Centrum pro studium demokracie a kultury (CDK), 2013, s. 653-668. 


\section{OBDOBÍ PO LISTOPADU 1989 AŽ DO TZV. MAJETKOVÉHO VYROVNÁNÍ STÁTU S CÍRKVEMI}

Ideologická a hospodářská vyčerpanost režimu vedla $\mathrm{v} \mathrm{k}$ událostem podzimu 1989, které vyústily až v jeho pád. Jedním z důsledků bylo i ukončení extrémního veřejného dozoru nad církvemi. Nastalo období jeho postupného rozvolňování, až téměř k hranici jeho zániku. Úplný odklon od principu veřejného dozoru nad církvemi byl bezesporu reakcí na silnou perzekuci v předchozích obdobích. ${ }^{28}$ Církve vstupovaly do nové éry v př́ivětivé společenské situaci ne tolik nepodobné období poválečnému. Společností bylo kladně reflektováno, že se jejich představitelé podíleli na boji s totalitním režimem. Ř́mskokatolická církev vstoupila do kontaktu s novou demokratickou vládou jako její partner. Tento kvalitativně nový vztah vyvrcholil vřele přijatou návštěvou papeže Jana Pavla II. Panovala celospolečenská shoda, že, mezi jinými, mají být napraveny i křivdy způsobené církvím. Velmi brzy však došlo, i vlivem snahy církví necitlivě ingerovat do veřejného prostoru, k ochlazení. Staré animozity v pohledu na náboženský život a postavení církví ve společnosti zjevně přetrvaly. Vztahu zajisté nepomohla ani role, kterou Svatý stolec sehrál v debatě o dělení federace, kdy byl, zejména z české strany podezírán, že stejně jako v letech válečných opět zvedá téma slovenského separatismu. ${ }^{29}$ Nicméně, zůstává faktem, že Svatý stolec nepotřeboval vyvíjet žádnou zvláštní aktivitu, směřující k narovnání vztahu církví ke státu. Federální vláda tak aktivně činila sama, nutno jí vytknout, že chaoticky a nekoncepčně. Co se týká obnovení autonomie vlastní správy církví, $\mathrm{k}$ přijetí klíčových rozhodnutí došlo v rozmezí pouhých tř́i let. V následujícím vývoji se již nepodařilo dohodnout plnohodnotný společenský konsenzus na úpravě vztahu státu k církvím a jejich financování. To vyústilo v přijetí řady kontroverzních norem, se kterými se většinová společnost neztotožnila a které byly často kritizovány i zevnitř církví. První kroky byly realizovány ještě v roce 1989, kdy byly zrušeny trestné činy v oblasti náboženství. V lednu 1990 došlo ke zrušení institutu udělování státního souhlasu k výkonu duchovní činnosti. Tím byla, ve prospěch církví, definitivně vyřešena staletá otázka ustanovování církevních hodnostár̆ù. V roce 1992 se stát zbavil možnosti napříště dozírat nad majetkem církví a ty s ním mohly začít volně disponovat. Tyto kroky nastartovaly proces částečné odluky církve od státu. Ve stejném roce se církvím vrátila možnost provést církevní sňatek s civilně právními účinky. ${ }^{30} \mathrm{Je}$ pozoruhodným paradoxem českých dějin, že zákon č. 218/1949 Sb., o hospodářském zabezpečení církví a náboženských společností státem, který sloužil státu jako nástroj pro represe vůči církvím, zůstal, ještě více jak dvacet let od roku 1989, stále účinný a byl následně využit jako jeden z nástrojů „osvobození církví“. Jedním z hlavních důvodů pro jeho přetrvávání byl letitý spor o financování církví. Klíčovým se ukázalo přijetí ústavního zákona č. 23/1991 Sb., kterým se uvozovala Listina základních práv

28 KAROLA, Petr. Problematika tzv. Církevních restituci po roce 1989. Praha, 2014. Diplomová práce. Karlova univerzita v Praze. Právnická fakulta. Katedra ústavního práva, s. 36.

29 HALAS, František X. Fenomén Vatikán: idea, dějiny a současnost papežství: diplomacie Svatého stolce: České země a Vatikán. 2., rozš. vyd. Brno: Centrum pro studium demokracie a kultury (CDK), 2013, s. 682.

30 TRETERA, Rajmund, Jiří. Stát a cirkve v České republice. Kostelní Vydř́: Karmelitánské nakladatelství, 2002, s. 53-54. 
a svobod jako ústavní zákon Federálního shromáždění České a Slovenské Federativní Republiky (dále jen „LZPS“) v roce 1991. Z pohledu obsahu nepřinesla nic, co by předchozí úprava, alespoň v rovině proklamací, již neznala. Rozdíl byl samozřejmě v jejím naplňování. Znovu byla otevřena otázka odluky. V roce 1991 Federální shromáždění přijímá zákon č. 308/1991 Sb., o svobodě víry a postavení církví a náboženských společností, konkretizující práva a svobody vycházející z LZPS. Jako odlukovém předpisu lze o tomto zákonu mluvit pouze částečně, nebot' tato vcelku prátelská odluka byla postavena na principu nezasahování státu do vnitřního života církví. Nicméně stále přetrvalo hluboké propojení státu s církvemi v rovině ekonomické. Důsledkem výše popsané reformy, v kombinaci s přijetím LZPS, byl úplný odklon od principu veřejného dohledu nad církvemi. Co se týká otázky majetku, v roce 1990 byl přijat zákon č. 403/1990 Sb., o zmírnění následků některých majetkových křivd, na který navazoval zákon č. 87/1991 Sb., o mimosoudních rehabilitacích. Dále došlo k přijetí zákona č. 229/1991 Sb. o úpravě vlastnických vztahů k půdě a jinému zemědělskému majetku, jež řš̌il restituci majetku ve sféree zemědělství. Tento zákon obsahoval ustanovení $§ 29$, pro který se vžilo pojmenování blokační. Ten bránil státu převést jím zatížený „bývalý“ majetek církví, a to až do doby, než bude v této věci přijat komplexní zákon. V roce 1991 došlo k přijetí zákona č. 172/1991 Sb. o přechodu některých věcí z majetku České republiky do vlastnictví obcí. Za vlastníky nezanedbatelné části údajného majetku církví tak prohlásil obce. ${ }^{31}$ Přijetí všech těchto předpisů, navíc v tak krátké době a bez široké společenské shody na odluce a formě jejího provedení se, $z$ dnešního pohledu, ukazuje jako zásadní chyba, která má značný dopad na stav vztahu společnosti a církví. Společenské i politické debaty se tak, po roce 1993, soustřed'ují v podstatě výhradně na otázku majetkového vyrovnání. Česká společnost neprošla žádnou hlubší diskuzí, jak se postavit k náboženskému životu, jeho úpravě i $\mathrm{k}$ tomu jakou roli by měly hrát církve ve společnosti. Přičemž právě to bylo, je a bude pro další bezproblémové soužití laické a věrící veřejnosti klíčové. V červenci roku 1990 byl přijat zákon č. 298/1990 Sb. o úpravě některých majetkových vztahů řeholních řádů a kongregací a arcibiskupství olomouckého, jehož účelem bylo umožnit zahájení činnosti řádů a kongregací. Tímto zákonem došlo k navrácení některého odňatého majetku řádů do jejich vlastnictví. Aby byl zajištěn jejich další rozvoj, byl v roce 1991 přijat ještě zákon č. 338/1991 Sb., který předchozí zákon doplňoval. Vzhledem $\mathrm{k}$ tomu, že se předpokládalo, že výše zmíněný blokační paragraf bude mít jen dočasnou existenci, bylo očekávání církví a náboženských společnost soustředěno na prosazení obecného zákona. Došlo tak, v roce 1992, skupinou poslanců Federálního shromáždění předložením zákona o majetkové restituci a rehabilitaci církví a náboženských společností. Tento návrh však obsahoval pouze složku restituční a neřešil otázku odluky a financování církví. Zákon nebyl Federálním shromážděním prijiat z důvodu nesouhlasu levicových stran a slovenské HZDS. ${ }^{32}$ Otázka jak přesně velkou roli a jestli vůbec, hrála Římskokatolická církev v rozpadu federace je i bezmála po třiceti letech neuzavřena. Nicméně zdá se, že tradičně silný slovenský

31 HRDINA, Ignác Antonín. Vztahy státu a církve v České republice v letech 1990-1999. Praha: Eurolex Bohemia, 2007, s. 33.

32 KŘİŽ, Jakub; VALES̆, Václav. Zákon o majetkovém vyrovnání s církvemi a náboženskými společnostmi: komentár. Praha: C. H. Beck, 2013, s. 48. 
katolicismus ve spojení s některými at' už promyšlenými či náhodnými kroky Svatého stolce a vystoupeními reprezentantů této církve, svoji roli v dělení mohli sehrát a to minimálně v oblasti tvorby veřejného mínění na Slovensku. Katolicky orientovaná slovenská emigrace začala o Slovenskou samostatnost bojovat záhy po revolučním období. Slovenské emigrační časopisy mluvili o podpoře slovenského separatismu ze strany papeže. Česká média na tuto hru přistoupila a spekulovala o této podpoře také. Úvaze o určitém vlivu nahrával i fakt, že tehdejší nejvyšší představitelé Slovenska, na rozdíl od těch českých, spoléhajících se na společnou federální zahraniční politiku, rádi pořádali slovenskou veřejností sledované návštěvy Svatého stolce a papeže především. V březnu roku 1991 papež přijal předsedu vlády Slovenské republiky Vladimíra Mečiara, v květnu předsedu Slovenské národní rady Františka Mikloška a na jaře 1992 pak předsedu vlády Slovenské republiky Jána Čarnogurského. ${ }^{33}$ Úplnou odpověd’ však nalezneme až po otevření př́ślušné části vatikánských archívů pro období devadesátých let, dvacátého století, jež nastane v polovině tohoto století. Faktem však zůstává, že další kolo jednání o řešení otázky majetku pokračovalo až po utvoření samostatné České republiky. Přímá jednání mezi vládou České republiky, Římskokatolickou církví a Ekumenickou radou církví probíhala v letech 1993 až 1997. Jenomže, po rozpadu federace došlo k zásadní změně poměrů. Před tímto rokem se český katolicismus mohl tradičně opírat o velmi silnou slovenskou podporu. Vztah Čechů k církvím a zvláště té Ř́mskokatolické již dávno nebyl tak vřelý, jako těsně v porevolučním období. Začaly se otevírat staré rány. Církve, od prvního sčitání lidu po revoluci, postihl masivní úbytek věřících, který pokračuje do dnes. Přitom se naopak předpokládalo, že dojde k masovému návratu $\mathrm{k}$ víře a náboženství. K první větši roztržce mezi Římskokatolickou církví a státem došlo již v roce 1993. Tradičně vznikl celý spor kvůli cyrilometodějské pouti na Velehradě, kam nebyl pozván tehdejší předseda vlády Václav Klaus. Navíc, arcibiskup Vlk zde velmi necitlivě zasvětil národ Panně Marii. Václav Klaus tak pout zhodnotil jako mocenskou demonstraci církve. To sice církev odmítla, ale díky tomuto incidentu byla jednání zablokována až do roku 1994. ${ }^{34}$ V období let 1993-1997 je velmi výrazná role Miloslava Vlka, který vytvářel trvalý tlak na vlády Václava Klause. Nicméně, i přesto ke vzájemně přijatelnému řešení situace nedošlo. ${ }^{35}$ Následně nastalo období vydávání majetku, tzv. exekutivní metodou. Na půdě Poslanecké sněmovny došlo k vytvoření soupisu majetku židovských obcí, jehož se exekutivní vydání mělo týkat. Ve své podstatě se jednalo o obcházení blokačního paragrafu. Dne 9. března 1994 vláda schválila návrh převodu majetku podle výše zmíněného soupisu. V roce 1996 vláda vydala ještě i usnesením o bezúplatném převodu vymezeného nemovitého majetku církevním právnickým osobám. $\mathrm{V}$ praxi došlo jen $\mathrm{k}$ vydání několika desítek budov

33 HALAS, František X. Fenomén Vatikán: idea, dějiny a současnost papežství: diplomacie Svatého stolce: České země a Vatikán. 2., rozš. vyd. Brno: Centrum pro studium demokracie a kultury (CDK), 2013, s. 684-686.

34 KOLÁ ̌́, Petr: Regnum, Sacerdotium Et Ordo Universalis. Praha, 2002. Dizertační práce. Karlova univerzita v Praze. Fakulta sociálních studií, s. 173.

35 SEKRETARIÁT ČESKÉ BISKUPSKÉ KONFERENCE. Přehled jednání mezi státem a církvemi v letech 1990-2000 [online]. Praha, 2001, s. 4-11. Dostupný z: http://www.cirkev.cz/res/data/004/000531.pdf [cit. 27. 1. 2018]. 
nebo pozemků. ${ }^{36} \mathrm{~S}$ nástupem vlády Miloše Zemana dochází k ustavení expertní komise, která se majetkovému vyrovnání státu s církvemi věnuje. Ta předkládá v roce 1999 dvě řešení. Financování církví a náboženských společností na základě vlastního vráceného majetku dle výčtového zákona a shromáždění nárokovaného církevního majetku ve fondu, z jehož výnosů by byly církve placeny. Česká biskupská konference, Federace židovských obcí a Ekumenická rada církví podpořily konstrukci fondu. S tím nesouhlasily čtyři církve - Pravoslavná, Československá husitská, Starokatolická a Apoštolská církev. Pro celé období vyjednávání je typické, že se postoje církví zastoupených v Ekumenické radě lišily. Byl zde rozpor mezi tím, co od řešení očekává Římskokatolická církev a tím co si přejí církve menší. Vláda Miloše Zemana je charakteristická předáním agendy expertním komisím. $\mathrm{K}$ dosažní shody však ani v tomto ani v následujícím čtyřletém období nedošlo. ${ }^{37} \mathrm{Od}$ druhé poloviny devadesátých let postupně navíc začíná růst tlak judikatury Ústavního soudu na předpokládané přijetí komplexního řešení otázky restituce majetku církví. Řešení celé situace se začalo rýsovat až za druhé vlády Mirka Topolánka. V roce 2007 byla zřízena Komise pro narovnání vztahu mezi státem a církvemi a náboženskými společnostmi. Ani její návrh však přijat nebyl, i když se stal základem pro úspěšně přijatý zákon č. 428/2012 Sb., o majetkovém vyrovnání s církvemi a náboženskými společnostmi (dále jen ,zákon o majetkovém vyrovnání státu s církvemi). Vláda Petra Nečase zř́dila v roce 2011 další komisi a nakonec to byla právě ona, která dokázala prosadit komplexní řešení. Jako předloha byl použit neúspěšný návrh z doby vlády premiéra Mirka Topolánka, kombinující naturální restituci s finanční náhradou a směřující cestou úpravy vztahů s církvemi do budoucna, zejména co se týče útlumu jejich financování ze státního rozpočtu. Blíže nespecifikovanou část finanční náhrady měly tvořit prostředky nutné $\mathrm{k}$ realizaci hospodářské a finanční odluky a část měla nahrazovat majetek, který z objektivních důvodů církvím vydat nešlo. Poměr těchto náhrad nebyl nikdy důkladně vysvětlen ani specifikován. Přijetí tohoto zákona provázely značné kontroverze a spory, a to nejenom na půdě Parlamentu, ale i uvnitř vládní koalice. Nakonec došlo až k rozštěpení koaliční strany Věci veřejné a právě za pomoci jejich bývalých členů, kteří tuto stranu opustili, byl zákon přijat. Následně byl potvrzen i Senátem. Prezidentem zákon nepodepsal, ale vzhledem k tomu, že zákon sněmovně nevrátil, jednalo se pouze o symbolické gesto. S odstupem času je třeba konstatovat, že na návrhu nevznikl ani politický a už vůbec ne společenský konsenzus, navíc byl protlačen kontroverzním způsobem. Zejména jeho druhá část, definující úpravu vztahů státu s církvemi do budoucna nebyla s veřejností seriózně komunikována. Jedná se tak o jakousi zastřenou, pozvolnou odluku. Zákon, i přesto, že se tak o něm obecně mluví, není čistě restituční. Jedná se o hybrid mezi restitučním a odlukovým předpisem. Rozsah majetku vráceného církvím nebyl nikdy řádně identifikován, byl pouze odhadnut. Z odhadu celkového rozsahu majetku byl pak i odhadnut majetek, který církvím vydat nelze. $Z$ jednou odhadnutých rozsahů byla odhadnuta jejich hodnota.

36 VALEŠ, Václav. Restituce cirkevního majetku v České republice po roce 1989. Brno: Moravsko-slezská křest’anská akademie, 2009, s. 38.

37 Česká republika. Vláda. Sněmovní tisk číslo 580/0. VI. volební období. Důvodová zpráva k zákonu č. 428/2012 Sb. ze dne 11. ledna 2012 Obecná část [online], s. 20. Dostupný z: http://www.psp.cz/sqw/text /tiskt.sqw? $=6 \& \mathrm{CT}=580 \& \mathrm{CT} 1=0$ [cit. 27. 1. 2018]. 
Z nepřesně určených rozsahů a jejich diskutabilního ocenění byla vypočítána finanční náhrada za majetek, který vydat nelze..$^{38}$ Tento předpis považuji osobně za jednu z největších překážek harmonického vztahu laické společnosti s církvemi a „nášlapnou minu pro budoucnost“. Následný vývoj, který dal vzniknout stovkám žalob církevních právnických osob, tuhému odporu samosprávných jednotek i neutuchajícím snahám o revizi jednou přijatého řešení značné části politického spektra tomu dal za pravdu. Na závěr této kapitoly nesmíme rozhodně opomenout zákon č. 3/2002 Sb. o svobodě náboženského vyznání a postavení církví a náboženských společností (dále jen ,zákon č. 3/2002 Sb.“), který nahradil v roce 2002 zákon č. 308/1991 Sb., ještě z dob federace. Ani přijetí této normy se neobešlo bez tradičních kontroverzí a problémů. Předpis byl odmítnut jak Senátem tak vetován prezidentem. Kritiku sklidil i od církví, protože měl omezovat jejich význam jen na šírení a vyznávání víry a zapomněl na společenskou úlohu církví, spočívající ve službě bližnímu. Oprávněně bylo kritizováno, že zákon církvím brání zřizovat a provozovat vlastní zařízení např. v oblasti sociálních služeb. ${ }^{39}$ Proti zákonu podala ústavní stížnost skupina senátorů a docílila zrušení jeho nejspornějších částí. Následně byla podána ještě jedna stížnost, a to v souvislosti s novelou z roku 2005. Nicméně, toto podání již bylo Ústavním soudem zamítnuto. Ještě je krátce nezbytné zmínit osud podepsané, avšak nikdy neratifikované smlouvy se Svatým stolcem, která měla nahradit prvorepublikový Modus vivendi. Byla podepsána dne 25. července 2002 tehdejším místopředsedou vlády a ministrem zahraničních věcí Cyrilem Svobodou a v př́ípadě ratifikace měla zásadním způsobem měnit základní principy dřive přijatého zákona č. 3/2002 Sb. Smlouva byla Poslaneckou sněmovnou 21. května 2003 zamítnuta. Její návrh zvýhodňoval, v rozporu s většinovým stanoviskem společnosti, Římskokatolickou církev na úkor církví a organizací ostatních a poskytl by jí řadu privilegií. Jejím prijietím by stát rezignoval na ideu své laickosti a prrijal by uvedení katolické církve do pozice církve státní. Stát by se vzdal značné části své suverenity vůči orgánům církevního zahraničního subjektu. ${ }^{40}$ Text smlouvy představoval jen další pokus o navrácení alespoň části v minulosti ztracených privilegií. Vztah státu s katolickou církví tak zůstal na mezinárodní úrovni zatím oficiálně nestvrzen.

\section{SOUČASNÝ STAV A ZÁVĚR}

Dnes žijeme v době, kdy se církvím pomalu „vrací“ majetek o který přišla v rozmezí od roku 1918 do roku 1989. Josefínské reformy i to, co začalo s T. G. Masarykem je prakticky nulováno. A tím se v podstatě uzavřel kruh. Zbývá tak jen historická pamět' české společnosti a její setrvávající skeptický vztah k víre a Římskokatolické církvi. Potvrzením narušeného vztahu je vrcholící debata o zdanění tzv. církevních

38 KAROLA, Petr. Problematika tzv. Cirkevnich restituci po roce 1989. Praha, 2014. Diplomová práce. Karlova univerzita v Praze. Právnická fakulta. Katedra ústavního práva, s. 55-59, 146-147.

39 PŘIBYL, Stanislav: Český zákon o církvích z roku 2002 a jeho změny. Revue církevního práva 3/2006, S. 195.

40 PAVLÍČEK, Václav. O české státnosti: úvahy a polemiky. 3. Demokratický a laický stát. Praha: Karolinum, 2009, s. 186. 
restitucí, kterou jsem ve své předchozí práci předpovídal ${ }^{41}$. Církvím byla navrácena, vedle „svobody ducha“ i absolutní svoboda ekonomická. I když je třeba zdůraznit, že spíše než o navrácení práv, jde o jejich nové přiznání, protože církve jich v takové míře $\mathrm{u}$ nás $\mathrm{v}$ uplynulém století nepožívaly. Bodem zlomu se z mého pohledu stalo právě přijetí zákona o majetkovém vyrovnání s církvemi a náboženskými společnostmi, který začal psát zcela novou kapitolu působení církví na našem území. S penězi se vrací vliv a rostou ambice hrát $\mathrm{v}$ české společnosti výraznější roli. Důsledky toho můžeme vidět v mnoha aspektech života. Církve začaly, stejně jako u sousedi̊, podnikat a investovat peníze vyplacené z finanční náhrady i z každoročního příspěvku na podporu činnosti, který mají zákonem garantován až do roku 2030. Vyrábějí a prodávají prostředky denní potřeby, zakládají minipivovary, ubytovací zařízení i restaurace. V Olomouci Římskokatolická církev založila dokonce společnost zaměřující se na sjednávání výhodnějších telefonních tarifů u operátorů a distributorů energií. Římskokatolická církev, která pobírá největší část finanční náhrady (v poměru $80 \%$ pro ni a $20 \%{ }^{42}$ pro ostatní církve), založila investiční růstový, výnosový a v roce 2017 fond nemovitostní. Výše finanční náhrady vyplacená Římskokatolické církvi za rok 2015 činila 1,282 miliardy Kč. Částka je každý rok upravováno o inflaci a vyplácení skončí v roce 2043. Př́spěvek na podporu činnosti ve stejném roce činil 892 miliónů Kč. Každý rok se snižuje o 5\%. Př́mé platby ze státního rozpočtu na činnost skončí v roce 2030 a finanční náhrada až v roce 2043. Po tomto roce tedy konečně dojde k plnému oddělení církví od státu i ve finanční rovině. Růstový fond investuje do cenných papírů a spravuje jej ČSOB Asset Management. V roce 2015 do něj Římskokatolická církev investovala celkem 798 miliónů Kč. Výnos tohoto fondu dosáhl v roce 2016 6,8 \%. Nemovitostní fond provádí investice do zemědělské půdy, lesní půdy a komerčních i kancelářských prostor. Výnos všech diecézí činil za rok 2015 celkem 994 miliónů Kč, z toho byl výsledek hospodaření po zdanění 108 miliónu korun. ${ }^{43}$ Církve se důkladně chystají na ukončení financování činnosti ze strany státu, nicméně tato chvíle je zatím ješte př́liš vzdálená. Církve nebyly ze strany státu $\mathrm{v}$ novodobých dějinách nikdy tak masivně ekonomicky podporovány a daňově zvýhodňovány. A s ekonomickou silou se vrací ambice. Téměř nemine týden, kdy bychom při oficiální státní akci neviděli někoho z čelních představitelů církví. Česká společnost reflektuje řadu událostí, kterým dávno odvykla a které dávají vzpomenout na obrazy z dávné historie otevírající staré jizvy, jako byla např. mše v katedrále sv. Víta, k 60. výročí zahájení vysílání Československé televize, př́ípadně mše za prezidenta republiky daná v Lánech. Umně některé církve využily i vyostřené atmosféry za vrcholící migrační krize $\mathrm{v}$ roce 2015 , kdy na schůzce $\mathrm{s}$ některými členy vlády, $\mathrm{v}$ čele s tehdejším ministrem vnitra Milanem Chovancem dohodli zástupci České biskupské konference a Ekumenické rady církví, že budou v utečeneckých táborech v Jordánsku a Kurdistánu

41 KAROLA, Petr. Problematika tzv. Církevních restitucí po roce 1989. Praha, 2014. Diplomová práce. Karlova univerzita v Praze. Právnická fakulta. Katedra ústavního práva, s. 143.

42 KAROLA, Petr. Problematika tzv. Cirkevnich restituci po roce 1989. Praha, 2014. Diplomová práce. Karlova univerzita v Praze. Právnická fakulta. Katedra ústavního práva, s. 47.

43 SURMANOVÁ, Kateřina. Hlavní investice katolické církve: Cenné papíry a nemovitosti ze dne 22. 12. 2016. ceskapozice.lidovky.cz [online]. 2016. Dostupný z: http://ceskapozice.lidovky.cz/hlavni -investice-katolicke-cirkve-cenne-papiry-a-nemovitosti-pun-/tema.aspx?c=A161219_173411_pozice -tema_lube [cit. 28. 1. 2018]. 
pomáhat vybírat uprchlíky, které stát plánoval prijimout, aby tak naplnil své povinnosti vyplývající z azylové legislativy. Historické reminiscence s tzv. Kazatelnicovým paragrafem vyvolávají veřejná doporučení církevních představitelů koho volit ve volbách, např. v roce 2013, kdy někteří zástupci Římskokatolické církve, Českobratrské církve evangelické či Církve bratrské výslovně podpořili před druhým kolem prezidentských voleb Karla Schwarzenberga. Zatím se tak nikdy nestalo skrze oficiální církevní orgány, které ještě stále respektují, že tak, dle vnitřních církevních předpisů, činit nemohou. Není třeba zdůrazňovat, že tyto kontroverzní kroky ohrožují společenské postavení nejenom Římskokatolické církve, ale i církví a náboženských společností ostatních. Nelze se tak př́liš divit tomu, že znovu ožívají tendence trend rozvolnění veřejného dozoru a ekonomické podpory církví obrátit zpět. Podporu návrhu Komunistické strany Čech a Moravy o zdanění finanční náhrady vyplácené církvím dle zákona o majetkovém vyrovnání státu s církvemi vyjadřuje současný premiér a předseda nejsilnější parlamentní strany Andreje Babiš i třetí v pořadí Tomio Okamura a jeho SPD. Souhlas s tímto návrhem, a to nejenom ze strany politických stran, ale i ze strany širší veřejnosti vyplývá z faktu, že její významná část cítí křivdu ohledně způsobu, jakým bylo provedeno majetkové vyrovnání a nastaven vztah s církvemi. Který nebyl dostatečně konzultován ani rádně vysvětlen a odůvodněn. Určité nebezpečí představuje pro budoucí soužití laické a věřící veřejnosti rovněž plánované přijetí ústavního zákona o obecném referendu, vyplňující mezeru v čl. 2, odst. 2 ústavního zákona č. 1/1993 Sb., Ústavy České republiky. Vůli k jeho přijetí deklarovala většina politických stran zastoupených v Poslanecké sněmovně Parlamentu a mohl by, v konečném důsledku, posloužit jako nástroj radikální změny postoje státu $\mathrm{k}$ církvím. Jestli nakonec dojde $\mathrm{k}$ přehoupnutí onoho pomyslného kyvadla zpět $\mathrm{k}$ zpř́snění veřejného dozoru státu nad církvemi, se zatím nedá korektně posoudit. Nicméně, z hlediska staletého vývoje vztahu našeho státu s církvemi i v širším dějinném kontextu by se nejednalo o žádné překvapení, naopak, spíše o přirozený chod věcí.

Historický vývoj vztahu státu s církvemi prošel od vzniku Československa dramatickým vývojem, svědčícím o tom, že vztah českého národa $\mathrm{k}$ církvi, zvláště té Římskokatolické, bude i nadále problematický a plný možných kontroverzí. Dějinný požadavek odluky nebyl ani po sto letech stále důsledně naplněn a jen budoucnost ukáže, jestli se tak vůbec někdy stane. Ukazuje se, že některé křivdy se ani při nejlepší vůli zhojit nedaří a vzájemný vztah se tak neustále točí v bludném kruhu křivd, jejich odpuštění a křivd nových. Vina je zjevně na obou stranách „barikády“. U státu spočívá v neschopnosti jeho politické reprezentace naplnit očekávání společnosti na formu a obsah historického vyrovnání, nemluvě o neschopnosti své jednání vysvětlit. U církví pak souvisí s přehnanými ambicemi a předkládanými novými nároky. To souvisí i s postupným mravním vyprázdněním české politiky, která již dávno přestala být soubojem myšlenek a idejí a zvrhla se ve střet o ekonomický prospěch. U Římskokatolické církve, resp. přinejmenším u části jejich českých nejvyšších představitelů situaci zhoršuje nepochopení hloubky ran zasazených jejich předchůdci. Církvím škodí i to, že odmítají přijmout fakt, že se znovuobnovená česká statnost, alespoň do jisté míry, zrodila z odporu proti jedné z nich. Ostatní církve a náboženské společnosti tak zůstávají rovněž rukojmím tohoto sváru. České společnosti bych proto přál, u př́ležitosti sta let 
od založení Československa hlavně více vzájemného pochopení a v dalších desetiletích především harmonické soužití její laické i věřící části. Obě strany se rozhodně mají v budoucnu čím obohatit.

JUDr. Petr Karola

doktorand katedry ústavního práva

Právnická fakulta Univerzity Karlovy

karola.petr@seznam.cz 